\title{
Political connections and corporate performance: Evidence from Pakistan
}

\author{
Abubakr Saeed $^{1 *}$, Yacine Belghitar $^{2}$ and Ephraim Clark ${ }^{3}$
}

\author{
${ }^{1}$ Abubakr Saeed, COMSATS University, Islamabad, Pakistan. \\ Email: abubakr.saeedd@comsats.edu.pk \\ ${ }^{2}$ Cranfield School of Management, Cranfield University, Bedford, UK \\ ${ }^{3}$ Department of Accounting and Finance, Middlesex University, London, UK
}

\begin{abstract}
This study seeks to understand how political connections affect firm performance. Using a hand-collected dataset of Pakistani firms during 2008-2014, our firm fixed effects and Heckman two-stage regression results show that connected firms outperform those without political ties. Moreover, we show channels though which political benefits are realized in terms of greater access to debt, lower financing costs and lower tax rates. These benefits are found to be particularly large when firms are connected to politicians who held political positions most recently and firms connected through their owners. Finally, we do not find evidence for differences in political favours across regulated and unregulated industries.
\end{abstract}

Keywords: Political Connections; Performance; Political Environment; Access to credit market; Effective Tax rate; Political Strength 


\section{Introduction}

The existing empirical evidence acknowledges both positive and negative returns to political connections. On the one hand, the existing studies indicate that having political connections deteriorate the controlling function of the board (You and Du, 2012), increase the risk of diverting the firm's resources to political objectives (Shleifer and Vishny, 1994), and decrease in performance due to lower managerial incentives (Saeed et al., 2016; Claessens et al., 2008). On the other hand, studies document that political connections facilitate firms in accessing bank loans and other funds (Infante and Piazza, 2014; Faccio, 2010; Li et al., 2008), improve performance (Boubakri et al., 2012a; Du and Girma, 2010), lower the cost of equity (Boubakri et al., 2012b), increase the probability of bail-out (Faccio et al., 2006), and improve firm's chances of acquiring government contracts (Tahoun, 2014) or subsidies (Zhang et al., 2014). Taken together, the existing empirical evidences are equivocal in assessing the impact of political connections on firms' decisions.

In this paper, we report further empirical evidence on the consequences of political connections and show that how the political affiliation of listed companies impact their performance. To conduct this study, we use Pakistan as our empirical setting for a number of reasons. First, political connections are commonplace in Pakistan and have a large impact on firm behaviour. In fact, in the past one and half decade, three assemblies and the prime ministers were dissolved against charges of political patronage, corruption and maladministration; such situations imitate the extensive level of political corruption, which significantly affect organization behaviour. Second, contrary to prior researches from the emerging countries which captured the political patronage is a narrow way, where organizational political outcomes can only be attained by a strong affiliation with a single powerful political actor (Mahathir in Malaysia and Suharto in Indonesia) ${ }^{1}$, and many politicians in Pakistan are in position to advantage their allied companies. In addition, the capacity to attain political profits depends on the power of politician. In this regard, Pakistani political landscape offers a wide variation in level of influence that politicians can exert to benefit connected firms. Third, in the last decade, Pakistan undertook drastic steps to curb political corruption. According to new law public officials and politician must declare their assets. Additionally, the National Anti-Corruption Strategy (NACS) was introduced in 2002 with to purpose to reduce corruption stems from the political system. However, the effectiveness of these steps is questionable, as the process of accountability is obstructed in various ways, for instance, a

\footnotetext{
${ }^{1}$ For instance, these studies include Johnson and Mitten (2003) and Fisman (2001).
} 
constitution bill was passed to give exemption to the armed forces and judiciary from the accountability process, and the NRO (National Reconciliation Ordinance) was introduced which granted amnesty to the accused politicians for the corruption and abuse of power. Therefore, the question whether politically connected firms in Pakistan benefit from political support is still not clear. These features provide a natural and excellent research setting to examine whether and how political connectedness effect firm performance? We consider two channels through which political connections are realized: access to credit market and effective tax rate.

Moreover, unlike developed economies where cronyism takes the form of formal favorable policies and subsidies, and political favouritisms in emerging economies usually appear in the form of preferential credit, utility bill exemptions and tax incentives ${ }^{2}$. Of these political benefits, utility bill exemptions are difficult to measure in Pakistan and data is unavailable. Therefore, in this study we rely on access to bank loan, cost of finance and tax benefits as channels through which connections pay off. In the context of Pakistan, the extent of annual corporate tax evasion is between Rs 700 billion to Rs 1 trillion (almost 21\% of GDP in year 2012) which is generally done through utilizing political influence. Similarly, the volume of written-off loans in last decade, mostly on political interferences, amounted to Rs. 96 billion which may project the role of politics in corporate lending. These facts are illustrative of the widespread tax avoidance and political rent provision in the economy.

To examine the impact of political connections on firm performance, we employ the firm fixed effect model and Heckman two-stage estimation technique. Using a hand-collected data of political connections of Pakistani firms during the period 2008-2014, our results reveal that firms having political connection show a better performance in terms of ROA and Tobin's Q than those without any political association. The empirical findings of the study further indicate that political ties enable firms to have greater access to the loans (measured as the ratio of book value of total debt to total assets) and at the same time, lower their financing costs (proxied by interest expenses scaled by total liabilities) and connected firms pay taxes at significantly lower rates (proxied by effective tax rate) in Pakistan. These results are robust to

\footnotetext{
${ }^{2}$ Implementation of favourable public policies is also one of the mechanisms for channelling political favour to connected firms which is widely observed in certain developing countries such as Thailand, Indonesia and Malaysia (Bunkanwanicha and Wiwattanakantang, 2009). However, in the context of Pakistan, this is not a viable strategy to extract political benefits because the ruling and opposition party members share the same business interests. They either own or affiliate with Sugar mills, steel industry or textile industry. So, any change in regulations and economic policies (to either safeguard their business or to curb the opponents) ultimately affect both parties.
} 
alternative estimation techniques, alternative proxy of political connections, industry adjusted variables, and alternative sample.

In additional analyses, we show that connections with politicians having political position most recently exert a larger impact on the political favours, which suggests that the benefits associated with the political connections ultimately rest on political strength of connected politician. We also examine whether the connections through board members or firm owners drive these effects. We find that connections through firm owners are more valuable for firms; however we can't negate the economic value of connections through corporate board members. Lastly, these political benefits are compared across regulated and unregulated industries. In contrast to earlier studies (e.g., Civilize et al., 2015), we do not find evidence for larger political benefits in regulated industries.

This study advances the existing literature along three lines. Firstly, our research contributes to a growing literature by exploring the likely channels through which political benefits may be realised (Infante and Piazza, 2014; Faccio, 2010; Li et al., 2008; Baum et al., 2008). We further show that political benefits depend on the type and political strength of connection. To do so, we construct several measures of the strength of political connections by distinguishing between the political connection through owner and director, and affiliation to ruling and opposition party, and the most recent political appointment. By doing this, we extend the work of Khwaja and Mian (2005) who show that Pakistani firm connected to politicians enjoy preferential treatment in credit market. Unlike Khwaja and Mian (2005), who employed the bank lending data and examine their lending patterns, we use the firm-level data and distinguish between strength of politician by various ways to examine the performance consequences of political connectedness and finding the channels through which these benefits can be realized. Our results for connections through owners are particularly unique and pertinent to countries in which the businessmen seek elections oneself to use public office to expand their businesses. This political strategy is more effective in countries where governments frequently change hands, makes it more costly for firms to maintain connections with individuals with recent political positions. Such short-term governments are observed worldwide, for example, in Bangladesh, Thailand, Nigeria, and Georgia.

Secondly, our results contributes to the existing body of knowledge on the performance consequences of connections in emerging markets (e.g., Claessens et al., 2008; Arnoldi and Muratova, 2018; Lu, 2011; Khwaja and Mian, 2005). Being a transitional economy, Pakistani economy is experiencing significant institutional changes and market institutions are still in their infancy (Settle, 2016). To overcome the difficulties caused by the lack of market- 
supporting institutions, establishing managerial political ties is an inevitable response of firms operating in such environment. Pakistan has also a long tradition of using connections to achieve business goals (Jan Pehchan in Urdu), and success of a business in Pakistan is heavily depends on connections (McCarthy et al. 2012). In addition, the government in Pakistan composed of at two levels: national (federal), and provincial. Politicians at national level assume greater power as compared to those at provincial levels (due to the fact that economic resources lie with the federal government), exhibiting the existence of wide variation in the political influence within the Pakistani political landscape. Employing the empirical setting with such distinctive contextual features, indeed, expands our knowledge by offering a new insight into how business environment affect the consequences of corporate political connections.

Lastly, we show that political connections play an important role in the determination of firm performance, debt decisions and effective tax rate (e.g., Dyreng et al., 2017; Koksal and Orman, 2015; Gupta \& Newberry, 1997). This effect is beyond the well-known firm specific determinants of these outcomes. Thus, understanding of the firm performance can be enriched substantially if we focus on the corporate political activities in addition to the other firm's characteristics.

This paper unfolds as follows. The next section introduces the business-politics nexus in Pakistan and presents the Pakistani income tax policy. Section 3 discusses the development of the hypotheses. Section 4 explains the nature of the data and discusses the empirical design. The section 5 presents the results. Lastly, Section 6 presents the conclusions.

\section{Political connections and Pakistani context}

\subsection{Business-Politics Nexus}

Politics in Pakistan has been connected with corruption, clientelism and rent-seeking. Pakistan is ranked amongst the most corrupt countries (Khwaja and Mian, 2005). The cases of corruption on the past three prime minister and their assemblies illustrate the extent of political corruption which has passed through the Pakistani economy during recent decades.

The economy of Pakistan has largely been dependent on agriculture and related industries from its very establishment, which has given rise to two elite groups-migrated industrialists and landowners; they quickly and overwhelmingly controlled most of the country's industry and commerce (Monshipouri \& Samuel, 1995). Most industrialists were involved in politics from the beginning of the country's establishment-arguably with the aim 
of protecting and expanding their interests. For example, Yusuf Haroon, a renowned industrialist, was the Chief Minister of Sindh at the creation of Pakistan and politicians like Naseer A Shiekh, Rafiq Saigol and Ahmad Dawood were the founding owner of the various business groups (Rehman, 2006). The current leadership of the leading political parties is also controlled by business tycoons ${ }^{3}$. Politicians in the government connected with business groups have also protect their business benefits. For example, a leading Pakistani newspaper, The News, during 2002-2007, documented how, United Bank Limited (UBL) and National Bank of Pakistan (NBP) allotted loan of Rs. 120 million to the President of PML-Q (Chauhadry group) against their sugar and textile mills on special terms, which were later written off.

\subsection{Income tax policy and compliance}

Pakistan is amongst those countries which have lowest tax-to-GDP ratios, tax to GDP ratio of Pakistan has been moving around $9 \%$ for the last few years. This indicates that the tax base remains constricted and a minor portion of the country is heavily taxed. According to a World Bank study, the tax gap (tax evasion) has increased from 69 percent to 79 percent during 2008 to 2012. Corporate tax rate in Pakistan is $35 \%$ which is much higher than the global average of $25.5 \%$ and regional ASEAN average of $27.5 \%$.

Against this backdrop, the governments have tried to reform Pakistan's tax system. The central government offered a reduction in tax rate to small firms and Association of Persons (AOPs) in an effort to increase the revenue collection and to encourage the investment. Under the Stand-By arrangement with IMF in October 2008, Pakistan agreed to move ahead with substantive tax policy and administrative reforms. Despite all rhetoric of tax reforms in the last decade or so, no significant progress is visible in tax revenue. This is mainly because the tax enforcement in Pakistan is notoriously weak and government is failing to tackle endemic corruption in tax machinery. In such an environment, companies and individuals avoid paying taxes because the risk of detection is very small and if they do get caught they can use political influence to find the way out.

According to the Federal Board of Revenue, 60 percent of Pakistan's cabinet and two third of its federal lawmakers did pay little or no income tax in 2011, despite an estimated average net wealth of $\$ 882,000$. According to the report, current President Asif Zardari (also owner of Sakrand Sugar Mill, Pangrio Sugar Mills, and Bachani Sugar Mills) did not file a tax

\footnotetext{
${ }^{3}$ Nawaz Sharif (owner of Ittefaq Foundries) is the president of Pakistan Muslim League (PML) and Chauhadry Shujaat Hussain (owner of Chauhadry Group) is the president of PML-Q. Pakistan People's Party leadership has been dominated by the landowners in the beginning, but currently it is headed by Asif A. Zardari, who is a leading industrialist.
} 
return in 2011. Similarly, former Railway Minister Ghulam Ahmad Bilour (Owner of Bilour Enterprises) did not pay tax in 2011 and neither did 34 of the 55 cabinet members file tax returns. Astonishingly, Commerce Minister Makhdoom Amin Fahim—also a member of board of directors of Service Group of Industries - does not even possess a national tax number ${ }^{4}$. These facts are illustrative of the widespread extent of tax evasion and the corruption norms within the economy. A similar level of tax evasion is anticipated from the corporate sector when they appoint politicians to their boards.

\section{Theory and hypotheses development}

In this section, the main hypotheses to be tested in this paper are developed. These hypotheses are as follows:

\section{Political connections and firm performance}

According to the resource-based view, a firm's competitive advantage lies in obtaining valuable tangible and intangible assets that are difficult or at least excessively costly for competitor firms to obtain. The political economy literature has long noted that political relationships are valuable resources to individual firms which exert positive impact on profitability (e.g., Saeed et al., 2015; Faccio, 2010; Fisman 2001).

Owing to positive affect, there are many reasons behind why politically connected organizations outperform than non-connected organizations. Most importantly, access to the main resources form the government results in the competitive advantage, which can be seen into better profitability (Faccio, 2010; Li et al., 2008; Chang \& Wong, 2004). Moreover, politicians connected with firms are usually outsiders to business world; they provide an independent view that ultimately enhances firm financial performance (Niessen \& Ruenzi, 2010). Lastly, politicians have more access to information relating to future economic strategic policies, so they are in the better position to help firms in making profitable decisions for the near future avenues. Empirical evidence to support this argument is sufficient. In a seminal work, Fisman (2001) estimated the value of political connections in Indonesia and reports that rumours of Suharto's deteriorating health adversely affected the stock price performance of the firms related to the president. Goldman et al. (2011) look at the effect of political connections on the allocation of procurement contracts in US and find that the government favours in allocating procurement contract to connected firms which effect positively on their long-term

\footnotetext{
4 "Over 60 percent of Pakistani lawmakers use their political influence to evade taxes" published in the Dawn, a Pakistani newspaper, on December 12, 2012.
} 
performance. Ferguson and Voth (2008) explore the political ties of German industrial organizations to the Nazi party in early 1933 and observe positive stock market performance for firms with substantial ties with Nazi party after the Nazi party rose to power. In a crosscountry study, Faccio (2006) finds a positive association between political connections and firm financial performance. In Malaysian market, Johnson and Mitton (2003) observe a strong positive correlation between stock market performance and political connections. Lastly, Boubakri et al. (2012a) report that politically connected organizations gain financial profits from their connections with politicians.

However, there are studies contradict these findings. Studies documenting the insignificant or negative association between firm's political ties and financial performance have a standpoint that boards of political connected firms does not have managerial incentives to increase shareholder's value and firm profitability (Shleifer and Vishny, 1994). For instance, based on a sample of 245 privatized firms from 41 countries, Boubakri et al. (2008) document that connected firms show poor performance compared to those firms lacking such ties. Faccio (2010) finds that in spite of the advantages they obtain, firms linked with political connections exhibit poor accounting performance compared to their non-connected counterparts. Bertrand et al. (2007) and Fan et al. (2007) report the same pattern in France and China, respectively for firms with political connections.

Taken together, empirical research brings us to the conclusion that there is mixed evidences at best on the effect of political ties on firm profitability. However, given the weak legal system, lack of institutional stability and pervasive rent-seeking behaviour that characterize many developing countries, the benefits from political connections frequently outweigh the costs of these connections. We, therefore, anticipate a positive impact of political connections on firm performance in terms of ROA and Tobin's Q in Pakistan, leading to the following hypothesis.

Hypothesis 1: Ceteris paribus, politically connected firms have better performance than nonconnected firms.

\section{Mechanisms through which political connections payoff}

As discussed above, earlier studies recognise various economic advantages that firms can gain from establishing connections with politicians, which include: preferential access to finance, receiving favourable regulatory treatment, allocation of government contracts, obtaining government bailout in case of financial trouble and paying lower taxes. Desai \& Olofsgard 
(2011) illustrates that, political favours in developing countries typically appear in the form of preferential credit to certain organizations, utility bill exemptions and tax deduction. Of these political benefits, utility bill exemptions are difficult to measure in Pakistan and data is unavailable. Therefore, in this study we rely on access to credit market (which includes level of indebtedness and cost of finance) and tax benefits as channels through which connections pay off.

Anecdotal evidence shows that politically affiliated firms in different countries enjoy preferential treatment in credit market. For example, Khwaja \& Mian (2005) argue that politically connected organization get loan to almost double of non-politically connected organizations, and the default rate is $50 \%$ higher on these credits. The lending pattern is highly dominant for stated owned banks rather than privately held banks. In a similar vein, Charumilind et al. (2006) report that politically connected Thailand organizations had greater access to long-term loans with less collateral needed. They employed various methods for political connections and they argue that political ties are the important antecedents of firm's future loans. Based on firm level data from Brazil, Claessens et al. (2008) show that following the Federal deputy elections, political connections have a positive relationship with bank leverage.

Largely, these studies set forth two important reasons for preferential access to credit market as most prevalent outcome of political ties. First, political influence is supposed to be greater over lending decisions than over other regulatory decisions as the decision making of banks commonly reflects the policies dictated by the government. Second, extorting better loan terms for favoured firms is likely to garner less public attention than other regulatory favours such as implementing laws to limit or handicap competitors. In view of this discussion, it seems safe to conclude that preferential bank credit is one of the most pervasive mechanisms used by politicians to benefit their associated firms. Effectively, this easier access to financing encourages firms to utilize more debt in financing decisions. Equally important is the fact that larger debt does not necessarily signify a better deal for the company if the interest rate of the loan is high. So, it is crucial to investigate does the connected firms avail lower interest rates.

Regarding tax deduction benefits, there are two foremost advantages of employing taxation as a measure of government related benefits. Firstly, it has a direct and definite impact on a firm's net income than other benefits, such as a favourable regulatory treatment. Secondly, since taxes are collected by the government therefore tax benefits are a more direct reflection of the functions of the politically connected directors. Examining the tax compliance of firms in Malaysia, Adhikari et al. (2006) investigate the link between effective tax rate and corporate 
political connectedness in Malaysian context. They find that firms with political relationships pay tax at significantly lower effective rate than firms lacking such relationships. This notion is also investigated by $\mathrm{Wu}$ et al. (2012), who provide evidence on the impact of politically connected managers on the tax benefits received by firms in Chinese market. Their results divulge that effective tax rates of private firms having political ties are lower than that of private firms without such ties.

Based on these lines of reasoning, we predict that:

Hypothesis 2a: Ceteris paribus, politically connected firms have higher leverage and lower financing cost than non-connected firms.

Hypothesis 2b: Ceteris paribus, politically connected firms pay lower taxes than nonconnected firms.

\section{Research design}

\subsection{Data sources and sample selection criteria}

The data for this study is taken from three different sources. First, financial data is taken from the OSIRIS, over the period 2008-2014. OSIRIS covers publicly listed financial and nonfinancial companies worldwide with a large selection of variables, and claims to provide annual accounting items for up to 10 years. However, the coverage differs greatly from one country to another, with better coverage for developed economies. Second, the data on politicians, which is gathered with the aim to locate the firms with political connections - is hand-collected, gathered from several sources including Election Commission of Pakistan (ECP), State Bank of Pakistan and from official reports of the several regulatory bodies. Third, to supplement the ownership information provided in OSIRIS, we hand-collect information on ownership for some firms using additional sources (a book by Rehman (2006), newspapers, firm Web sites, annual report, etc.).

Our data gathering process starts from obtaining a list of firms listed on Karachi Stock Exchange as of 2008. This list provided us the names of 651 listed firms, of which 169 firms belong to financial sector. After excluding the financial firms, 482 firms were searched in Osiris database (to gather the firm-level data on them) and we found 361 non-financial Pakistani firms in the database. Subsequently, the data availability of these 361 firms was checked in OSIRIS and 18 firms were found to have missing information on key variables including financial variables, ownership structure, and board of directors. Off these 18 firms, 
13 firms (3.6\%) had no information on board composition and other key variables used the study during the entire period, and remaining 5 firms had missing information on financial variables. Regarding ownership data (shareholding pattern), most of the information is obtained from OSIRIS, however various other sources such as firm webpage, newspaper, annual reports were also consulted to complement the ownership data. Finally, we have to drop 18 firms with missing information from the sample. The resulting final sample comprises 2401 firm-year observations of 343 non-financial listed firms. Each firm in the study sample does contain the same number of time-series observations, and so this dataset is a balanced panel data.

\subsection{Variables measurement}

Measure of firm performance: Although there are various accounting measures centred on quantifying performance in the literature, for the purpose of this study, however, two measures are adopted-return on assets and Tobin's Q_in common with similar works studying the outcomes of political connections on firms' performance (Boubakri et al., 2008; Dombrovsky, 2008; Fan et al., 2007). Return on assets is the ratio used in order to assess the ability of firms to generate return on the total assets available for application. This is defined as profit before taxes over total assets. Tobin's Q is a market-oriented measure of a firm's performance, shows firm's ability to create shareholders' wealth (Su and Fung, 2013). Tobin's Q is constructed as the market value of equity plus book value of total debts divided by the book value of total assets.

Measure of access to credit market and tax rate: We use two variables related to access to credit market, namely, total debt $(D E B T)$ and financial expense ratio-cost of finance (FINANCOST). Similar to Su and Fung (2013) and Boubakri et al. (2012a), total debt is defined as the ratio of the book value of a firm's total debt (short-term and long-term) to the total assets, a proxy for the size of total loans. Further, financial expense ratio is interest expenses divided by total liabilities. Most Pakistani firms use bank loans to raise funds rather than issue bonds (Ashraf \& Ghani, 2005); therefore, the debt of company is regarded as a bank loan and measured by their book value.

A firm's tax rate is measured by the effective income tax rate (ETR). To be consistent with the previous studies (Wu et al., 2012; Adhikari et al. 2006), we consider the current portion of tax, measured as tax expenses minus deferred tax expenses, and scale it with firm profit. While measuring the profit, the difference between accounting profit and tax profit need to be considered. The accounting profit might not accurately represent the actual taxable income of 
the firms. Furthermore, dissimilar accounting policies would yield different incomes. So, to counter the difference in profit measurements, Zimmerman (1983) suggests the usage of cash flow instead of operating income. Subsequently, several studies have also adopted the suggested mechanism to calculate ETR (i.e. Gupta \& Newberry, 1997). In the same spirit, we measure ETR as the ratio of tax expenses minus deferred tax expenses divided by operating cash flow.

Measure of political connectedness: Following mainstream literature (Boubakri et al., 2012a; Faccio, 2010; Khwaja \& Mian, 2005), an organization is considered politically connected if it has a politician on its board of directors. A person is considered as politician if he/she holds (or previously held) the position of prime minister, state minister, minister from the prime minister's office, member of national or provincial cabinet, or head of the regulatory and supervisory bodies. To collect the information on politicians, we consulted official websites of Election Commission of Pakistan, State Bank of Pakistan and official reports of the several regulatory bodies. We supplement these sources with information available on the Internet. For each individual in database we establish their name, surname, political position and duration of political position. Subsequently, a politician's name is matched to a company's director if their full name (obtained from the OSIRIS) matches exactly that company is then defined as politically connected company. By so doing, 97 politicians were matched to firms' directors. No politician was matched to more than one firm; therefore, 97 firms were identified as politically connected firms. In our analysis, firm's political connectedness is represented by POLCON, a time-variant dummy variable taking one if firm has a politically connected director, and zero otherwise.

Table 1 presents the distribution of the sample firms based on political connections and type of connection. From Table 1, we can see that 97 firms (with 604 firm-year observations) are politically connected. Of these connected firms, $29 \%$ are connected through their owner and $71 \%$ are connected through directors. Finally, $63 \%$ connections involve politicians who belong to the ruling party.

Control variables: We also include several firm level characteristics as controls in our analyses. Specifically, we follow earlier literature and identity control variables that have been found correlated with firm performance and other financing decisions (Su \& Fung, 2013; Wu et al., 2012; Dombrovsky, 2008; Fan et al., 2007; Adhikari et al. 2006) In doing so, we control for the economies of scale or firm size by taking natural logarithm of total assets (SIZE), tangible 
assets which is fixed assets divided by total assets (COLLATERAL) and firm' operating cash flow $(O P E R C F)$ measured as firm's operating cash flow divided by total assets. Data on operating cash flow is obtained from firm's cash flow statement. In line with Fan et al. (2007) and $\mathrm{Wu}$ et al. (2012), we take the fraction of common shares held by the largest shareholders (LARGESHARE). Next, following Su \& Fung (2013), we use the proportion of independent directors serving on the board (INDEPEND) to measure the quality of firm level corporate governance. The literature on corporate governance (e.g. Agrawal \& Knoeber, 2001) shows that owing to the presumed independence of independent directors they are in a better position to monitor managerial activities which facilitate aligning managerial and shareholder interests. Accordingly, the presence of outside directors on board is expected to be linked with improved firm performance.

\subsection{Estimation model}

One potential concern in our analyses is the endogeneity problem which has to be considered in regression estimates. Corporate political connection may not be exogenous which means some unobservable determinants of performance and financing decisions may also explain political connections. In other words, board connectedness and performance may be jointly determined by unobservable firm-specific variables Moreover, it is also possible that firm's likelihood to be politically connected may determine by the performance, which causes the simultaneous endogenity. To tackle the endogenity issue caused by unobservable firm specific variables and reverse causality, we use fixed effect estimation as our preferred estimation technique and compare the results with estimator obtained from Heckman's two-stage approach (Heckman, 1979).

\section{Fixed effect estimation model}

Fixed effects estimation technique is considered as a widely accepted method of controlling for omitted variables bias in a panel data set (see Wintoki, 2007). By using firm fixed effects model on panel data, we can exploit the variation for same firm across years to obtain a clean identification. Specifically, we use firm fixed effects and industryxtime fixed effects to control for unobserved heterogeneity ${ }^{5}$. The fixed effect model specification is as follows:

\footnotetext{
5 Industry fixed effects are based on the two-digit SIC code defined in Campbell (1996). Following the methodology of Cambell, firms are distributed among following eight industries: Food \& Tabaco (36), Basic industries including petroleum (57), Construction (49), Textile \& trade (128), Consumer durables (33), Transportation (9), Services (11), and others (20).
} 


$$
\begin{aligned}
\text { INDICAT }_{i, t}= & a+\beta_{1} \text { POLCON }_{i, t}+\beta_{2} \text { SIZE }_{i, t}+\beta_{3} \text { COLLATERAL }_{i, t}+\beta_{4} \text { OPERCF }_{i, t} \\
& +\beta_{5} \text { LARGESHARE }_{i, t}+\beta_{6} \text { INDEPEND }_{i, t}+\alpha f_{i}+\alpha+\alpha \times \lambda_{t} \\
& +\varepsilon_{i, t}
\end{aligned}
$$

where INDICAT refers to the firm performance (PERFORMANCE), debt level (DEBT), cost of finance (FINANCOST), and effective tax rate (ETR). POLCON indicates political connectedness which is a dummy variable indicating the political connection of a firm. Furthermore, firm size (SIZE), collateral (COLLATERAL), operating cash flow (OPERCF), fraction of common shares held by the largest shareholders (LARGESHARE) and proportion of independent directors (INDEPEND) are control variables. Finally, $f_{i}$ are firm fixed effects, $\alpha$ are industry fixed effects representing unobservable industry characteristics; $\lambda_{t}$ are year fixed effects and $\varepsilon$ is the error term. The interaction term of industry and time fixed effects absorbs the changes occurred over the years at the industry level, for instance, regulatory measures for a certain industry.

\section{Heckman two-stage regression}

Heckman two-stage regression technique is designed to control for the firm's selection into political connectedness on the basis of performance and other financial characteristics. The model consists of two stages as follows:

First-stage regression: Determinants of political connections:

The first stage of the procedure involves a probit model to estimate the determinants of firm's probability to establish political connection. Specifically, the model for the first-stage regression is:

$$
\begin{aligned}
\text { POLCON }_{i, t}= & a+\beta_{1} Z_{i, t}+\beta_{2} \% \text { CONNECTED_FIRMS_INDUSTRY }_{i, t}+\beta_{3} \text { LOCATION }_{i, t} \\
& +\alpha+\lambda_{t}+\varepsilon_{i, t}
\end{aligned}
$$

where POLCON is a dummy variable which indicates the political connection of a firm that is regressed against all other firm-level control variables (Z), plus instrumental variables (selection model variables). In particular, based on prior research on political connections, we employed firm size, collateral, operating cash flow, proportion of common shares held by the largest shareholders and proportion of independent directors as control variables. Further, following Kim and Zhang (2016), Boubakri et al. (2012a), Chaney et al. (2011) and Agrawal \& Knoeber (2001) we include percentage of connected firm in an industry (\% 
CONNECTED_FIRMS_INDUSTRY) and the firm's location (LOCATION) - a dummy variable takes value 1 if the firm is located in the two largest cities of the country, namely, Karachi and Lahore - is selected as an instrument of political connections. Earlier studies have evidently reported that these variables relate only to the political connections-not with other political benefits. Similar argument may apply to the location variable. Lastly, $\alpha$ are industry fixed effects representing unobservable industry characteristics; $\lambda_{t}$ are year fixed effects and $\varepsilon$ is the error term. To avoid some problems of endogeneity at this stage, all independent variables are lagged one year.

\section{Second-stage regression: Outcomes of political connections}

In the second stage, we regress various outcomes of political connections (performance, leverage, cost of finance and effective tax rate) on the political connectedness after controlling for firm-level variables (as shown below in models 2), and the inverse Mills ratio obtained from the first regression.

The regression model used to test how political connections affect firm performance resembles those of Su \& Fung (2013), Boubakri et al. (2012a) and Li et al. (2008). It encompasses the following general form:

$$
\begin{aligned}
\operatorname{INDICAT}_{i, t}= & a+\beta_{1} \text { POLCON }_{i, t}+\beta_{2} \text { SIZE }_{i, t}+\beta_{3} \text { COLLATERAL }_{i, t}+\beta_{4} \text { OPERINC }_{i, t} \\
& +\beta_{5} \text { LARGESHARE }_{i, t}+\beta_{6} \text { INDEPEND }_{i, t}+\beta_{7} \text { MILLS }_{i, t}+\alpha+\lambda_{t} \\
& +\varepsilon_{i, t}
\end{aligned}
$$

where INDICAT refers to the firm performance (PERFORMANCE), debt level (DEBT), cost of finance (FINANCOST), and effective tax rate (ETR). POLCON indicates political connectedness. MILLS is inverse Mills ratio from stage-1 to control for selection bias. The Hypothesis 1 predicts a positive and significant coefficient for POLCON. In testing Hypothesis 2a, we expect $P O L C O N$ to be positive and significant for $D E B T$, whereas negative and significant for FINANCOST and ETR.

\section{Empirical results}

\subsection{Descriptive statistics}

Table 2 presents summary statistics for the dependent and explanatory variables that are used in the analysis. The average return on assets for the entire sample (in Panel A) is 4.99 and the Tobin's q is on average 7.30. The financial debt amounts to $68 \%$ of total assets and the average cost of debt is $3 \%$ of total assets. The effective tax rate for sample has a mean of 0.26. 
Panel B \& C provide preliminary univariate statistics for the sub-samples of connected firms and their non-connected peers. In Panel B, the results show a clear tendency for connected firms to be more profitable than non-connected ones. More specifically, the average return on assets for connected firms is 6.38 , which is significantly larger than the value for non-connected firms (4.53). Tobin's q shows an even greater difference. The debt of connected firms is significantly higher than that of their non-connected peers (71\% vs. $65 \%)$. Surprisingly, the cost of finance for connected firms is not significantly different from non-connected firms. Connected firms, however, enjoy significantly lower tax rate than their non-connected counterparts ( $32 \%$ vs. $21 \%)$.

Regarding other characteristics, Table 2 indicates that connected and non-connected firms differ in some aspects of their demographics and conduct. The former are larger, enjoy superior access to external finance and tend to possess large physical assets. Finally, politically affiliated firms are quite similar to non-affiliated firms in terms of growth opportunities, percentage of large shareholdings, and board structure.

\subsection{Main results}

\subsubsection{Fixed effect regression results}

We begin with performance as a dependent variable in regressions (Panel A) and subsequently access to credit market (Panel B) and effective tax rate (Panel C) are used as dependent variables in the estimations. Table 3 presents the results of the fixed effects estimations. As shown in Column 1 of Table 3, the coefficient of PC is significantly positive at the $1 \%$ level, which specifies that political connected organization have a higher ROA than those without connections. More specifically, the connected firms have a higher ROA of 0.031 percentage point than the non-connected organizations. To affirm our findings, we re-estimated our model with Tobin's $Q$. The impact of political ties on Tobin's $Q$ is also found to be positive. The results in Column 2 reveal that firms with political connections outperform non-politically connected firms by 0.054 percentage points. Regarding control variables, firms with larger size, having large collateral, adequate cash flow and large proportion of independent directors have, ceteris paribus, superior performance. The finding in both panels strongly support the first hypothesis and is in line with studies, such as Boubakri et al. (2012a) and Dombrovsky (2008), all of whom report superior performance for connected firms.

Taken together, the regression results show that firms with politically connected directors experience increasing performance regardless of whether performance is measured 
by return on assets or the Tobin's $Q$. The results are consistent with our hypothesis 1 and the univariate findings that connected firms outperform their non-connected counterparts. Our findings closely resemble findings in Fan et al. (2007), Faccio (2006) and Charumilind et al. (2006), all of which illustrate the determining role of connections on firm performance.

Access to credit market: We next examine the effect of political connections in the credit market. In Column 3 of Table 3, the variable of total size of credit, DEBT, is positively and significantly correlated with political connections, a result indicating that political connected firms receive more loans. Statistically, connected firms have a higher debt to assets ratio of 0.047 percentage points when compared to firms without such connections. This significant positive effect of political connection on size of debt lends support to our hypothesis 2a. Our result corroborates the anecdotal evidence that firms connected to politicians use more credit.

We now proceed to analyse whether or not political connections help firms in reducing finance cost. Columns 4 shows that the FINANCOST relates to political connections negatively, affirming that connected firms benefit from lower interest rates. This estimate indicates that interest rate is about 0.016 percentage points lower in firms with political connections. The coefficients of the inverse Mills ratio are significant in all models, suggesting that ordinary least square regressions likely bias the coefficients. .

The collective results lend support to Hypothesis 2a that political connections enable firms to obtain preferential treatment in credit market through easier access to finance and reduced cost of credit. The preferential treatment to connected firms complements the findings of prior studies such as Infante \& Piaza (2014); Su \& Fung (2013), and Asquer \& Calderoni (2011).

Effective tax rate: We now turn to alternative financing policy which may have effect of corporate political connectedness, namely, the tax benefits. In Panel $\mathrm{C}$ of Table 3, the coefficient of $P O L C O N$ is significantly negative (coefficient $=-0.034$, p-value $<0.01$ ). This represents that firms with political relationships have lower ETRs of 0.034 percentage point than those without such relationships. The regression results support our Hypothesis $2 b$ which predicts that firms having politically connected directors pay taxes at lower rate than other firms lacking such relationships.

Taken together, our regression results establish two important points so far. Firstly, we show that political connection is linked with substantial gains in performance. This superior performance is through preferential treatment in credit market and tax benefits. It is accordance with prior studies such as Faccio (2010), Li et al., (2008) and Chang \& Wong, (2004). 
Secondly, it is worth noticing that impact of political connections on cost of finance is weakest in comparison to the effect of connections on the size of loan obtained and tax rate. One potential explanation might be that connected firms accumulate loans with the intention of not being returned therefore they are least concerned with the cost of finance. It has also been reported in Khwaja \& Mian (2005) that wilfully defaulting on loans is indeed a notorious way of amassing funds by politically connected firms in Pakistan. Hence, we may state that due to default intentions, connected firms acquire less benefits though the channel of financing cost.

\subsubsection{Heckman two-stage regression results}

\section{First-stage regression results}

First-stage regression findings for the determinants of political connections are presented in Table 4. We find that firm size relates significantly positive with political connections, suggesting that firm size is a significant element of the likelihood of establishing political connections. Moreover, politically connected organizations have higher leverage. These results are in line with Chaney et al. (2011). Further, organizations located in Islamabad and Lahore tend to establish connections more frequently as compared to firms located elsewhere. Finally, politically connected firms come from more political active industries. These results corroborate with Kim and Zhang (2016).

\section{Second-stage regression results}

Table 5 presents the second-stage results. In Column (1) and (2), the coefficient on the interaction term between politically connected director's appointment and the period following the appointment enters positively and significantly for both measures of performance. In particular, the connected firms yield, on average, 0.023 percentage point higher return on their available assets than their non-connected peers. Similar finding is obtained for Tobin's Q. Result indicates that average market value difference between connected and non-connected firms is $4.6 \%$. It indicates that appointment of politically connected director increases the performance of connected firms. The value of MILLS is significant in both columns, showing the effectiveness of controlling for endogeneity of political connection variable. As for as control variables are concerned, large businesses and firms with large proportion of independent directors have better performance. Moreover, ownership of large shareholders exerts a positive effect only on Tobin's Q.

Further, in column (3) where debt is the dependent variable, the coefficient on the interactive term shows that appointing politically connected director exerts a positive and 
significant impact._The variable of total size of credit, $D E B T$, is positively and significantly correlated with political connections. Result indicates that politically affiliated firms receive more loans. In economic terms, it can be stated that connected firms, on average, have a higher debt to asset ratio of 0.065 percentage points as compared to their non-connected counterparts. This result lends support to our hypothesis $2 \mathrm{a}$.

Finally, in column (4\&5), the negative and significant coefficients on political connection variable indicate that connected firms avail loan at lower cost and have lower effective tax rates after appointing politically connected director as compared to control firms. In terms of economic value, connected firms bear lower debt cost of 0.009 percentage point and have lower effective tax rate of 0.029 percentage point. The negative and significant results for cost of loan and tax rate support our hypothesis $2 \mathrm{a}$ and $2 \mathrm{~b}$. The coefficients of the inverse Mills ratio are significant in all models, suggesting that ordinary least square regressions likely bias the coefficients. Overall, the results shown in this section confirm our earlier results and mitigate the endogenity concern at greater extent.

\subsection{Additional analyses}

\section{Connections through board of directors versus connections through owners}

Nevertheless, before concluding that political connections have determining role in firm performance, we delve a level deeper and consider that all connections might not be equally effective. For instance, connections through firm owner might be more valuable (ceteris paribus) than connections through board of directors because of their direct personal economic benefits coupled with the firm decisions. So, as an extension of our findings, we distinguish between the effects of the connections that are established via the board of directors and connections through the owners of the company. Following Faccio (2010), we define a firm connected through owner when the firm controlling shareholder — who owns at least $10 \%$ of the shares- is a politician ${ }^{6}$. Empirically, we split the 97 connected firms among firms that are politically connected through their directors (firms where politicians are only member of board of directors), and firms that are connected via their owners (firms where politicians are not only the member of board of directors but are also the company's owner) ${ }^{7}$. Multiple data sources are used to identify the firm ownership. Rehman (2006) provides detailed ownership

\footnotetext{
${ }^{6}$ This threshold choice is based on the literature (Faccio, 2006; Bunkanwanicha and Wiwattanakantang, 2009). By holding this level of ownership, controlling shareholders have incentives to bring resources to the company. ${ }^{7}$ Member of Board of directors include directors, CEO, CFO, Chairman, etc and we don't distinguish between them mainly because of the small number of connected CEOs and Chairmen in our sample.
} 
information. The missing ownership information for certain firms is gathered through other sources such as newspapers, websites and annual reports. Following this identification scheme, $29(27.10 \%)$ of the connected firms are connected through their owners. To empirically conduct this examination, we replace $P O L C O N$ variable (used in equations 2) with two dummies, POLDIRECTOR and POLOWNER, which indicate whether a firm is connected through director or owner, respectively. Panel A of Table 7 presents the results of fixed effect regressions. For brevity, regression estimates for control variables are not reported. In each model, POLDIRECTOR and POLOWNER are introduced separately in the regressions.

As shown in Panel A of Table 6, the coefficients of both POLDIRECTOR and POLOWNER are positive and significant. Specifically, both types of connections increase performance in terms of $R O A$ and Tobin's $Q$. The performance is found to be higher for firms connected through their owners. This evidence suggests that political benefits are larger if firm owners participate in the politics by themselves-directly protects their business interests. Columns (5-8) of Table 6 report the results for the size of credit used and the cost of finance variables. Similar pattern emerges from the regressions as observed earlier in Table 3 . The estimated coefficients on POLDIRECTOR and POLOWNER are statistically significant. This indicates that both types of connections benefit connected firms by providing easier and cheaper credit, however, companies connected through their owners are benefited more in credit market. Columns (9) and (10) of Table 6 present the results for effective tax rate. The results indicate that only firms connected through their owner enjoy lower tax rates whereas connections through directors do not affect firm tax rate.

Taken together, our results in Table 6 indicate that both connections, through directors and owner, have a valuable effect on business operations nevertheless latter is more important than the former in assessing the value of political capital.

\section{Political strength}

The prior studies shows that politically connected companies benefit more when they are connected to the politician having more influence (i.e., Infante \& Piaza, 2014; Asquer \& Calderoni, 2011). Belonging to ruling party and having political position ultimately increases the political strength of a politician in obtaining even greater governmental benefits therefore they are better able to provide political favours. To empirically test this conjecture, we replace political connection variable in earlier equations with two measures of political strength. First measure is a dummy variable POLCON_RUL indicating if the connected politician belongs to the ruling party or not. Second proxy POLCON_RECENT captures the recentness of director's 
most latest political position. Following Kim and Zhang (2016), it is defined as one divided by one plus the escalated years between the current year and that of the most recent political position of the connected director. For instance, the value of POLCON_RECENT is one if the firm has a director who holds a position in the current year. Empirically, we replace the political connection indicator in equation (2) witch one of the measures of political connection' strength. Results are shown in Panel B of Table 6. Results for both measures of political strength confirm our earlier results. However, the magnitude of coefficients indicates that directors with most recent political positions can provide additional benefits to their connected firms. The findings corroborate the earlier studies of Infante \& Piaza (2014) and Asquer \& Calderoni (2011).

\section{Impact of political connections across regulated and unregulated industries}

Some studies point out that the political favours for connected companies is more dominant in industries that are more dependent on government (e.g., Houston et al., 2014). Considering the fact that government in Pakistan has considerable power over resources allocation and regulatory changes, which tends to concentrate in regulated industries. This is particularly true for the energy, transportation, telecommunication, pharmaceutical, and technology sector. So it is expected that political favours tend to be higher in regulated sector. To test this notion, we stratify our sample into regulated and unregulated sub-samples and re-estimate our analysis separately on both sub-samples. Results are presented in Panel C of Table 6. In contrast to our expectations, empirical results do not find any evidence that political ties have a more favourable impact on firm financial performance and on other outcomes in regulated industries. In fact, benefits of being connected are almost the same across regulated and unregulated industries, as shown by Houston et al. (2014).

\subsection{Robustness tests}

\section{Exclusion of state-owned firms}

In our analysis, we include state-owned firms, which are expected to have higher political involvement compared to private firms. We suspect that inclusion of state-owned firms might have driven our results. To alleviate this issue, in Panel A of Table 7, we present firm fixed effect results using only private firms (we excluded 14 state-owned firms). Our main findings remain unaffected, which is, performance, leverage, cost of finance and effective tax rate continue to be affected by political connections.

\section{Industry-adjusted measures}


We re-estimate the regressions using industry adjusted dependent variables. In the empirical work, the measurement of industry-adjusted dependent variables is carried out by subtracting the specific value of firm $i$ from the median value of all firms in that industry. For example, industry-adjusted return on assets is defined as: [(ROA of firm i) minus (median value of ROA for all firms in firm i's primary two-digit SIC industry)]. Note that the sample is distributed among eight industry categories based on SIC as defined in Campbell (1996).

Panel B of Table 7 presents the firm fixed effect regression estimates using industry adjusted dependent variables. Again, the results are qualitatively similar to the earlier estimations. Although, the estimated coefficient for the POLCON in the performance model is smaller ( 0.015 and 0.032 for ROA and Tobin's $Q$, respectively) than that in the case without industry adjustments (0.023 and 0.046), nevertheless the direction of the relationship and statistical significance satisfy the hypothesis of political influence on the performance and other political outcomes. In sum, it can be concluded that our basic results are robust to industryadjusted measures. ${ }^{8}$

\section{Alternative measure of political connections}

We recognize the fact that our measure of political relationship does not consider the connections that may be established through relatives, friends, or similar educational institutions (also termed as indirect connections). Consequently, there is a concern that our results might underestimate the impact of political connections. To this purpose, we redefine corporate political connections broadly by including both direct and indirect connections. Following Asquer \& Calderoni (2011), indirectly connected company is defined as the one which has at least one friend or relative of a politician as the board of director. The information on indirect connections is retrieved from Pakistani newspapers, media reports and Internet. As an outcome, we found 11 cases of indirect connections, where board members are relative or friend of a politician. No firm is found to have more than one connected individual on board. Surprisingly, very small number of indirect connections is identified as compared to the direct connections. In part, this finding is due to the fact that Internet is not so developed in Pakistan and print media is under the political influence therefore the rate of success in detecting indirect connections remained very low.

\footnotetext{
${ }^{8}$ As a robustness check, firm performance is also measured in terms of firm investment. Firm investment is measured as change in fixed assets from year $t$ to $t-1$ divided by total assets in year $t$. The results show a positive and statistically significant impact of political connections on firm investment. These results are not reported for the sake of brevity.
} 
The firm fixed effect estimates, with a broader definition of political connection, are presented in Panel $\mathrm{C}$ of Table 7. Our main results remain unaffected, that is, connections with politicians insert positive effects on firm performance. Further, connected firms continue to take political advantages though preferential access to credit at reduced rate and paying lower taxes. This evidence suggests that inclusion of indirect connections does not change our basic result.

\section{System GMM estimation technique}

As robustness test, we re-estimate our main findings with system GMM (Arellano and Bond, 1991), which is one of the widely employed estimated techniques in finance. System GMM is considered as a superior technique due to the fact that it controls unobservable heterogeneity, simultaneity and dynamic endogeneity in the relationship between corporate outcomes and board structure. To control unobservable firm heterogeneity, system GMM includes not only firm fixed effects but also allows current values of political connections and control variables to be influenced by previous levels of these variables. This is an important aspect of a dynamic panel estimator. In addition, theoretically, firm appoints politically connected director to improve firm performance, while performance is affected by the appointment of connected director however the reverse may also be true. To solve the endogeneity problem caused by simultaneity, one way is to estimate the effect of appointment of connected director on firm performance using a system of equations. Estimating system of equations requires exogenous instruments which system GMM generates from lagged-value of original regressors. In fact, system GMM considers the underlying relationship between firm performance (or other financial decisions), political connections and control variables as dynamic. Therefore, it uses past values of and past changes in political connection and control variables as instruments, which also provides the convenience to the users. The important assumption for GMM technique is that error term must not be serially correlated which indicates the validity of instruments. For this purpose, we consider Sargan test of over-identifying restrictions test and second-order (AR-2) test.

Results are shown in Panel D of Table 7. The impact of political connections remains the same as earlier. Political connections continue to exert a positive and statistically significant effect on firm performance and connected firms still benefit from preferential access to credit at reduced rate and paying lower taxes. In sum, it indicates that our main results are robust to the sophisticated estimation techniques. 


\section{Conclusion}

This paper examines that whether or not political connections affect firm performance and what the channels are through which political connections pay off. To conduct this study, we rely on hand-collected firm-level data from Pakistani non-financial listed firms during the period 2008 to 2014. Using firm fixed effect method and Heckman two-stage model estimation technique, we find that political connections exerts a positive impact on firm performance a result that is robust to a battery of checks including industry-adjusted measures of the dependent variables, alternative sample and the alternative measure of political connections. Subsequently, we first document that political ties enable firms to access easy to debt at lower cost. Secondly, our findings show that connections facilitate firms to obtain tax cuts.

As an extension, we explore whether connections through directors or owners are more valuable for firms. The results suggest that both connections drive the beneficial effects of political connections; however, the impact is larger if firm establish connections via their owners. Moreover, the impact of political affiliations is more pronounced for companies connected with directors having most recent political positions. This evidence supports the view that connections with more influential individuals worth more. Lastly, we do not find evidence that the impact of political affiliations is more positive in regulated industries.

Importantly, we extended almost the same conclusions regardless of whether we used firm fixed effect method or Heckman two-stage estimator. Overall, these findings provide support to the crony capitalism view that connected firms benefit from their connections and better perform. 


\section{References}

Adhikari, A., Derashid, C. and Zhang, H. (2006). 'Public policy, political connections, and effective tax rates: Longitudinal evidence from Malaysia'. Journal of Accounting and Public Policy, 25: pp. 574-595.

Agrawal A. and Knoeber C.R. (2001). 'Do some outside directors play a political role?' Journal of Law and Economics. 44: pp. 179-98.

Arellano, M., and Bond, S. (1991). 'Some tests of specification for panel data: Monte Carlo evidence and an application to employment equations. The Review of Economic Studies, 58: pp.277-297.

Arnoldi, J. \& Muratova, Y. (2018). 'Unrelated acquisitions in China: The role of political ownership and political connections', Asia-Pacific Journal of Management, https://doi.org/10.1007/s10490-018-9571-2

Ashraf, J. and Ghani, W. (2005). 'Accounting development in Pakistan', The international Journal of Accounting, 40, pp. 175-201.

Asquer R. and Calderoni, F. (2011). 'Family matters: Testing the effect of political connections in Italy, Symposium: Democracy and Its Development 2005-2011, Centre for the Study of Democracy, UC Irvine.

Baum, C.F., Caglayan, M., Schäfer., D. and Talavera, O. (2008). 'Political patronage in Ukrainian banking. Economics of Transition, 16, pp. 537-557.

Bertrand, M., F. Kramarz, A. Schoar, and Thesmar, D. (2007). 'Politicians, Firms and the Political Business Cycle: Evidence from France', Working Paper.

Boubakri, N., Cosset, J. and Walid, S. (2008). 'Political connections of newly privatized firms', Journal of Corporate Finance, 14, pp. 654-673.

Boubakri, N., Cosset, J. and Walid, S. (2012a). 'The impact of political connections on firm's operating performance and financing decisions'. The Journal of Financial Research, 35: pp. 397-423.

Boubakri, N., Omrane, O., Mishra, D. and Walid, S. (2012b). 'Political connections and cost of equity capital'. Journal of Corporate Finance, 18: pp. 541-559.

Bunkanwanicha, P. and Wiwattanakantang, Y. (2009). 'Big business owners in politics', Review of Financial Studies, 22, pp. 2133-2168.

Campbell, J.Y. (1996). 'Understanding risk and return'. Journal of Political Economy. 104: pp. 298-345.

Chaney, P., Faccio, M. and Parsley, D. (2011). 'The quality of accounting information in politically connected firms'. Journal of Accounting and Economics, 51, pp. 58-76.

Chang, E.C. and Wong, S.M. (2004). 'Political control and performance in China's listed firms', Journal of Comparative Economics, 32, pp. 617-636.

Charumilind C., Kali R., Wiwattanakantang Y. (2006). 'Connected lending: Thailand before the Financial Crisis', The Journal of Business. 79: pp. 181-218.

Civilize, S., Wongchoti, U., and Young, M. (2015). 'Political Connections and Stock Returns: A Longitudinal Study'. The Financial Review, 50: pp. 89-119.

Claessens, S., Feijen, E., Laeven, L. (2008). 'Political connections and preferential access to finance: The role of campaign contributions'. Journal of Financial Economics, 88: pp. 554580. 
Desai, R.M., Olofsgard A. (2011). 'The Costs of Political Influence: Firm-Level Evidence from Developing Countries', Quarterly Journal of Political Science, 6: pp. 137-178.

Dombrovsky, V. (2008). 'Do Political Connections Matter? Firm-Level Evidence from Latvia', Stockholm School of Economics in Riga, BICEPS Working paper Series.

Du, J., Girma, S., 2010. 'Red capitalists: Political connections and firm performance in China'. KYKLOS. 63: 530-545.

Dyreng, S. D., Hanlon, M., Maydew, E.L., Thornock, J.R. (2017). 'Changes in corporate effective tax rates over the past 25 years'. Journal of Financial Economics, 124, pp. 441463.

Faccio, M. (2006). 'Politically connected firms', American Economic Review, 96, pp. 369-386.

Faccio, M. (2010). 'Differences between politically connected and non-connected firms: A cross country comparison', Financial Management, 39, pp. 905-927.

Faccio, M., Masulis, R., McConnell, J.J. (2006). 'Political connections and corporate bailouts'. Journal of Finance. 61: pp. 2597-2635.

Fan, J.P.H, Wong, T.J. and Zhang, T. (2007). 'Politically connected CEOs, corporate governance, and post-IPO performance of China's newly partially privatized firms'. Journal of Financial Economics, 84, pp. 330-357.

Ferguson, T. and Voth, H.J. (2008). 'Betting on Hitler-the value of political connections in Nazi Germany', Quarterly Journal of Economics, 123, pp. 101-137.

Fisman, R. (2001). 'Estimating the value of political connections', American Economic Review, 91, pp. 1095-1102.

Goldman, E., Rocholl, J., So, J. (2009). 'Do politically connected boards affect firm value?' Review of Financial Studies. 22: pp. 2331-2360.

Gupta, S. and Newberry, K. (1997). 'Determinants of the variability in corporate effective tax rate: evidence from longitudinal data'. Journal of Accounting and Public Policy, 16, pp. 139.

Heckman, J. (1979). 'Sample selection bias as a specification error'. Econometrica, 47, pp. $153-161$.

Houston, J., Jiang, L., Lin, C., Ma, Y. (2014). 'Political connections and the cost of bank loans'. Journal of Accounting Research, 52, pp. 193-243.

Infante, L. and Piazza, M. (2014). 'Political Connections and Preferential Lending at Local Level: Some Evidence from the Italian Credit Market', Journal of Corporate Finance, 29, pp. 246-262.

Johnson, S. and Mitten, T. (2003). 'Cronyism and capital controls: Evidence from Malaysia', Journal of Financial Economics, 67, pp. 351-382.

Kim, C.F. and Zhang, L. (2016). 'Corporate political connections and tax aggressiveness', Contemporary Accounting Research, 33, pp. 78-114.

Khwaja, A.I. and Mian, A.R. (2005). 'Do lenders favour politically connected firms? Rent provision in an emerging financial market', The Quarterly Journal of Economics, 120, pp. 1371-1411.

Koksal, B. and Orman, C. (2015). 'Determinants of capital structure: Evidence from a major developing country', Small Business Economics, 44, pp. 255-282. 
Li, H., Meng, H., Wang, Q. and Zhou L.A. (2008). 'Political connections, financing and firm performance: evidence from Chinese private firms', Journal of Development Economics, 87, pp. 283-299.

Lu, Y. (2011). 'Political connections and trade expansion: Evidence from Chinese private firms', Economics of Transition, 19, pp. 231-254.

Monshipouri, M. and Samuel, A. (1995). 'Development and democracy in Pakistan: Tenuous or plausible nexus?’ Asian Survey, 35, pp. 973-989.

Niessen, A. and Ruenzi, S. (2010). 'Political connectedness and firm performance: Evidence from Germany', German Economic Review, 11, pp. 441-464.

Rehman, U.R. 2006. 'Who owns Pakistan', 5th Edition, Islamabad: Mr. Books (Pvt.) Ltd.

Saeed, A., Belghitar, Y. and Clark, E. (2015). Political connections and firm leverage: Firm level evidence from Pakistan, Managerial and Decision Economics, 36, pp. 364-383.

Saeed, A., Belghitar, Y. and Clark, E. (2016). 'Do political connections affect firm performance: Evidence from a developing country', Emerging Markets Finance \& Trade, 52, pp. 1876-1891.

Settle, A. (2016). 'Locating financialization in a less-developed economy: Micro responses to liberalization and volatility in Pakistan', Competition and Change, 20, pp. 106-121.

Shleifer, A. and Vishny, R. W. (1994). 'Politicians and firms', Quarterly Journal of Economics, 109, pp. 995-1025.

Su, Z. and Fung, H.G. (2013). 'Political connections and firm performance in Chinese companies'. Pacific Economic Review, 18, pp. 283-317.

Tahoun, A., (2014). 'The Role of Stock Ownership by US Members of Congress on the Market for Political Favours', Journal of Financial Economics, 111, pp. 86-110.

Wu, W., Wu, C., Zhou, C. and Wu, J. (2012). 'Political connections, tax benefits and firm performance: Evidence from China', Journal of Accounting and Public Policy, 31, pp. 277300.

Zimmerman, J.L. (1983). 'Taxes and firm size'. Journal of Accounting and Economics, 5, pp. 119-149.

Zhang, H., Li. L., Zhou., D. and Zhou, P. (2014). 'Political connections, government subsidies and firm financial performance: Evidence from renewable energy manufacturing in China', Renewable Energy 63 p. 330-336. 


\section{TABLE 1. Sample distribution}

This table provides distribution of firms used in this study by connections and type of connections.

\begin{tabular}{lcccccccc}
\hline Years & $\mathbf{2 0 0 8}$ & $\mathbf{2 0 0 9}$ & $\mathbf{2 0 1 0}$ & $\mathbf{2 0 1 1}$ & $\mathbf{2 0 1 2}$ & $\mathbf{2 0 1 3}$ & $\mathbf{2 0 1 4}$ & Total \\
No. of non-connected firms & 262 & 265 & 259 & 249 & 256 & 261 & 264 & 1816 \\
No. connected firms & 81 & 78 & 84 & 94 & 87 & 82 & 79 & 585 \\
Total observations & 343 & 343 & 343 & 343 & 343 & 343 & 343 & 2401 \\
\% of connected firms & 30.91 & 29.43 & 32.43 & 37.75 & 33.59 & 31.41 & 29.92 & 32.21 \\
\hline
\end{tabular}

Distribution of connected firms by definition (2008-2014)

\section{Definition}

Politically connected through owner

Politically connected through director

Politically connected with politicians belong to the ruling party
Number $(\%)$

28(28.86)

$69(71.14)$

$61(62.88)$ 


\section{TABLE 2. Descriptive statistics}

This table presents descriptive statistics of the variables used in the analyses. ROA is the ratio of firm's return (profit before taxes) over total assets (coded in \%). Tobin's $\mathrm{Q}$ is constructed as the market value of equity plus book value of total debts divided by the book value of total assets. DEBT is ratio of the book value of a firm's total debt (short-term and long-term) to the total assets. FINANCOST is measured as interest expenses divided by total liabilities. ETR is the ratio of tax expenses minus deferred tax expenses divided by operating cash flow. POLCON is a dummy which takes one if there is a politician on board of directors, zero otherwise. SIZE is measured as log of the total assets of the firm. OPERCF is firm's operating cash flow divided by total assets. COLLATERAL is the fraction of fixed assets by total assets. LARGESHARE is the percentage of shares held by the largest shareholders. INDEPEND is the ratio of independent directors divided by total number of directors.

\begin{tabular}{|c|c|c|c|c|c|c|c|c|c|c|c|c|c|}
\hline & \multicolumn{4}{|c|}{$\begin{array}{c}\text { Panel A } \\
\text { Entire sample }\end{array}$} & \multicolumn{4}{|c|}{$\begin{array}{c}\text { Panel B } \\
\text { Political Connected firms }\end{array}$} & \multicolumn{4}{|c|}{$\begin{array}{c}\text { Panel C } \\
\text { Non-connected firms }\end{array}$} & \multirow{2}{*}{$\begin{array}{c}\text { Mean } \\
\text { difference } \\
\text { (t-statistics) }\end{array}$} \\
\hline & Mean & St. Dev & Min & $\operatorname{Max}$ & Mean & St. Dev & Min & $\operatorname{Max}$ & Mean & St. Dev & Min & $\operatorname{Max}$ & \\
\hline ROA & 4.99 & 10.72 & -13.72 & 11.85 & 6.38 & 11.25 & -13.67 & 9.91 & 4.53 & 10.28 & -13.72 & 11.85 & $-4.82 * * *$ \\
\hline Tobin's Q & 7.30 & 9.34 & 5.46 & 10.02 & 9.14 & 9.75 & 5.46 & 10.02 & 7.06 & 9.04 & 6.02 & 9.82 & $-6.19 * * *$ \\
\hline DEBT & 0.68 & 0.27 & 0.19 & 1.31 & 0.71 & 0.25 & 0.22 & 1.31 & 0.65 & 0.26 & 0.19 & 1.26 & $-3.41 * * *$ \\
\hline FINANCOST & 0.03 & 0.02 & -0.52 & 0.27 & 0.02 & 0.01 & -0.56 & 0.25 & 0.04 & 0.02 & -0.52 & 0.27 & 1.05 \\
\hline ETR & 0.26 & 0.18 & 0.02 & 1.45 & 0.21 & 0.16 & 0.04 & 1.45 & 0.32 & 0.19 & 0.02 & 1.33 & $2.18 * *$ \\
\hline SIZE & 6.41 & 0.68 & 4.91 & 8.33 & 6.39 & 0.64 & 3.73 & 7.56 & 6.30 & 0.65 & 4.91 & 8.33 & $-2.02 * *$ \\
\hline OPERCF & 1.24 & 3.16 & 0.02 & 2.07 & 1.18 & 3.39 & 0.02 & 2.01 & 1.31 & 3.42 & 0.03 & 2.07 & 1.64 \\
\hline COLLATERAL & 0.52 & 0.22 & 0.09 & 0.86 & 0.50 & 0.23 & 0.13 & 0.86 & 0.49 & 0.23 & 0.09 & 0.84 & $-0.70 * *$ \\
\hline LARGESHARE & 0.29 & 0.07 & 0.01 & 0.81 & 0.35 & 0.08 & 0.01 & 0.79 & 0.27 & 0.06 & 0.01 & 0.81 & -1.60 \\
\hline INDEPEND & 0.35 & 0.04 & 0.19 & 0.66 & 0.36 & 0.04 & 0.19 & 0.64 & 0.39 & 0.03 & 0.21 & 0.66 & 0.12 \\
\hline
\end{tabular}




\section{TABLE 3: Fixed effect regression results: Impact of political connections}

The table reports the regression results when political director is added on the board. All the variables are defined as follows. ROA is the ratio of firm's return (profit before taxes) over total assets. Tobin's Q is constructed as the market value of equity plus book value of total debts divided by the book value of total assets. DEBT is ratio of the book value of a firm's total debt (short-term and long-term) to the total assets. FINANCOST is measured as interest expenses divided by total liabilities. ETR is the ratio of tax expenses minus deferred tax expenses divided by operating cash flow. PC is an indicator variable for a firm belonging to the treatment group. POST is a dummy variable for the post-treatment period, equals to one for period after the politically connected director is appointed and zero for the period before. SIZE is measured as log of the total assets of the firm. COLLATERAL is the fraction of fixed assets by total assets. OPERCF is firm's operating cash flow divided by total assets. LARGESHARE is the percentage of shares held by the largest shareholders. INDEPEND is the ratio of independent directors divided by total number of directors. Standard errors clustered at firm level are in parentheses beneath the coefficient estimates, where $* * *, * *$ and $*$ denote statistical significance at the 1,5 and $10 \%$ levels, respectively.

\begin{tabular}{|c|c|c|c|c|c|}
\hline & \multicolumn{2}{|c|}{ Panel A: Firm performance } & \multicolumn{2}{|c|}{ Panel B: Access to credit market } & $\begin{array}{c}\text { Panel C: ETR } \\
\text { ETR }\end{array}$ \\
\hline & (1) & (2) & (3) & (4) & (5) \\
\hline POLCON & $(0.005)$ & $(0.012)$ & $(0.015)$ & $(0.008)$ & $(0.008)$ \\
\hline SIZE & $0.179 * * *$ & $0.201 * * *$ & $0.063 * *$ & $0.284 * * *$ & $-0.319 * * *$ \\
\hline COLLATERAL & $(0.035)$ & $(0.052)$ & $(0.113)$ & $(0.157)$ & $(0.516)$ \\
\hline \multirow[t]{2}{*}{ OPERCF } & $0.015 * * *$ & $0.026 * * *$ & $0.082 *$ & 0.012 & $0.041 *$ \\
\hline & $(0.002)$ & $(0.04)$ & $(0.040)$ & $(0.037)$ & $(0.020)$ \\
\hline \multirow[t]{2}{*}{ LARGESHARE } & 0.028 & 0.037 & 0.051 & $-0.096 *$ & -0.010 \\
\hline & $(0.073)$ & $(0.109)$ & $(0.128)$ & $(0.042)$ & $(0.029)$ \\
\hline Industry $\times$ Time fixed effects & Yes & Yes & Yes & Yes & Yes \\
\hline Observations & 2401 & 2401 & 2401 & 2401 & 2401 \\
\hline Number of firms & 343 & 343 & 343 & 343 & 343 \\
\hline Within $\mathrm{R}^{2}$ & 0.26 & 0.22 & 0.31 & 0.23 & 0.19 \\
\hline
\end{tabular}




\section{TABLE 4: First-stage regression results: Determinants of corporate political connections}

This table reports the probit regression results where dependent variable is POLCON. POLCON is a dummy which takes one if there is a politician on board of directors, zero otherwise. SIZE is measured as log of the total assets of the firm. COLLATERAL is the fraction of fixed assets by total assets. OPERCF is firm's operating cash flow divided by total assets. LARGESHARE is the percentage of shares held by the largest shareholders. INDEPEND is the ratio of independent directors divided by total number of directors. \% CONNECTED_FIRMS_INDUSTRY is the percentage of connected firm in an industry and LOCATION is a dummy variable takes value 1 if the firm is located in the two largest cities of the country, namely, Karachi and Lahore. Standard errors clustered at firm level are in parentheses beneath the coefficient estimates, where ***, $* *$ and $*$ denote statistical significance at the 1,5 and $10 \%$ levels, respectively.

\begin{tabular}{lc}
\hline & Dependent Variable: POLCON \\
\hline SIZE COLLATERAL & $0.346^{* * *}$ \\
& $(0.04)$ \\
OPERCF & $0.118^{* * *}$ \\
& $(0.29)$ \\
LARGESHARE & 1.340 \\
& $(2.453)$ \\
INDEPEND & 0.379 \\
& $(0.547)$ \\
\% CONNECTED_FIRMS_INDUSTRY & 0.026 \\
& $(0.075)$ \\
LOCATION & $0.231^{* *}$ \\
& $(0.075)$ \\
Years FE & $0.401^{* *}$ \\
Industry FE & $(0.137)$ \\
Number of Obs. & Yes \\
Number of firms & Yes \\
Pseudo R-Squared & 2401 \\
& 343 \\
\hline
\end{tabular}




\section{TABLE 5: Second-stage regression results: Impact of political connections}

The table reports the coefficients for Heckman's second-stage regression, where the variables are defined as follows. ROA is the ratio of firm's return (profit before taxes) over total assets. Tobin's Q is constructed as the market value of equity plus book value of total debts divided by the book value of total assets. DEBT is ratio of the book value of a firm's total debt (short-term and long-term) to the total assets. FINANCOST is measured as interest expenses divided by total liabilities. ETR is the ratio of tax expenses minus deferred tax expenses divided by operating cash flow. POLCON is a dummy which takes one if there is a politician on board of directors, zero otherwise. SIZE is measured as log of the total assets of the firm. COLLATERAL is the fraction of fixed assets by total assets. OPERCF is firm's operating cash flow divided by total assets. LARGESHARE is the percentage of shares held by the largest shareholders. INDEPEND is the ratio of independent directors divided by total number of directors. INVERSE-MILLS is inverse Mills ratio obtained from the probit regression (first-stage of Heckman selection model). Standard errors clustered at firm level are in parentheses beneath the coefficient estimates, where $* * *, * *$ and $*$ denote statistical significance at the 1,5 and $10 \%$ levels, respectively.

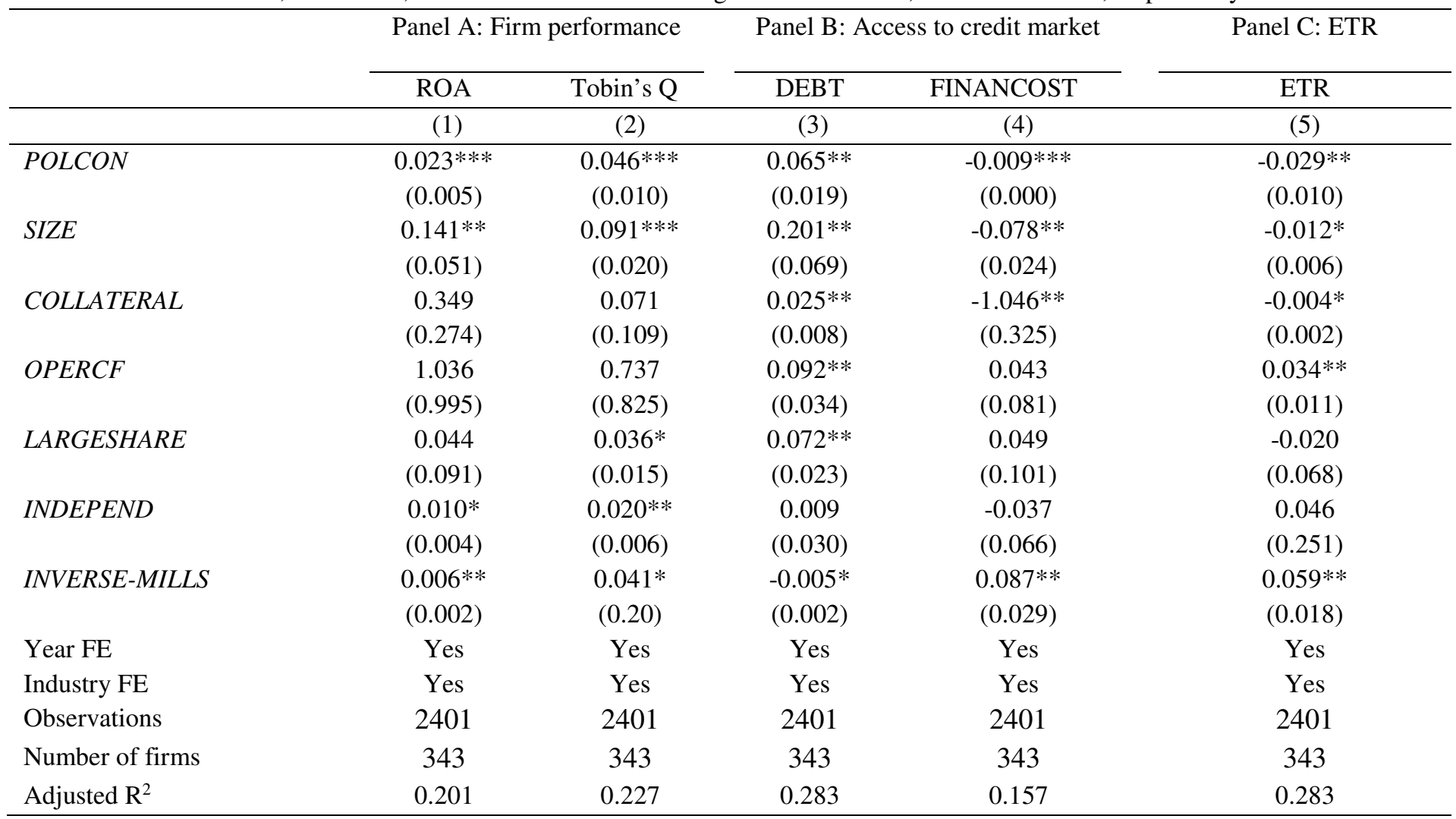




\section{TABLE 6: Additional tests}

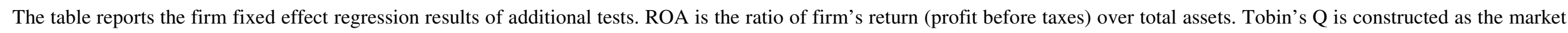

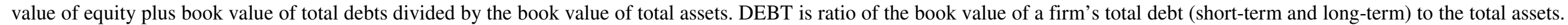

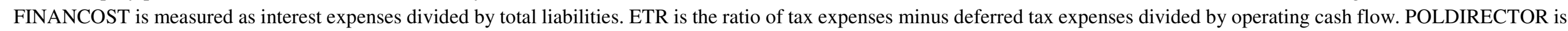

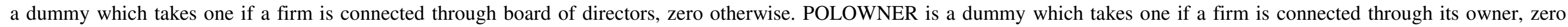

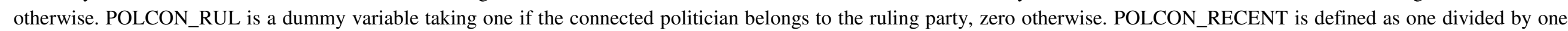

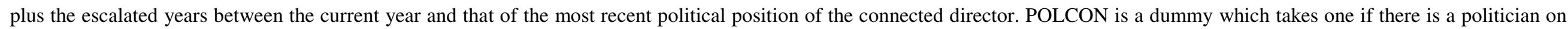

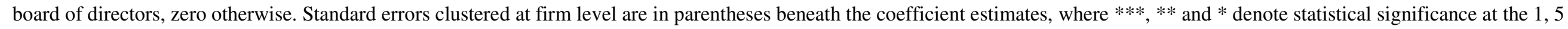
and $10 \%$ levels, respectively.

Panel A: Impact of political connections through board of directors and connections through owner

\begin{tabular}{|c|c|c|c|c|c|c|c|c|c|c|}
\hline & \multicolumn{4}{|c|}{ Firm performance } & \multicolumn{4}{|c|}{ Access to credit market } & \multirow{2}{*}{\multicolumn{2}{|c|}{$\frac{\text { Effective tax rate }}{\text { ETR }}$}} \\
\hline & \multicolumn{2}{|c|}{ ROA } & \multicolumn{2}{|c|}{ Tobin's Q } & \multicolumn{2}{|c|}{ DEBT } & \multicolumn{2}{|l|}{ FINANCOST } & & \\
\hline & (1) & (2) & (3) & (4) & (5) & (6) & (7) & (8) & (9) & (10) \\
\hline \multirow[t]{2}{*}{ POLDIRECTOR } & $0.020 * * *$ & & $0.040 * *$ & & $0.056^{* * *}$ & & $-0.008 * * *$ & & -0.025 & \\
\hline & $(0.002)$ & & $(0.012)$ & & $(0.003)$ & & $(0.001)$ & & $(0.097)$ & \\
\hline \multirow[t]{2}{*}{ POLOWNER } & & $0.031 * * *$ & & $0.055 * *$ & & $0.081 * *$ & & $-0.009 * * *$ & & $-0.033 * * *$ \\
\hline & & $(0.004)$ & & $(0.016)$ & & $(0.026)$ & & $(0.000)$ & & $(0.005)$ \\
\hline Control Variables & Yes & Yes & Yes & Yes & Yes & Yes & Yes & Yes & Yes & Yes \\
\hline Firm fixed effects & Yes & Yes & Yes & Yes & Yes & Yes & Yes & Yes & Yes & Yes \\
\hline Industry $\times$ Time fixed effects & Yes & Yes & Yes & Yes & Yes & Yes & Yes & Yes & Yes & Yes \\
\hline Observations & 2401 & 2401 & 2401 & 2401 & 2401 & 2401 & 2401 & 2401 & 2401 & 2401 \\
\hline Number of firms & 343 & 343 & 343 & 343 & 343 & 343 & 343 & 343 & 343 & 343 \\
\hline Adjusted $\mathrm{R}^{2}$ & 0.198 & 0.215 & 0.304 & 0.291 & 0.205 & 0.164 & 0.402 & 0.335 & 0.227 & 0.200 \\
\hline
\end{tabular}


Panel B: Impact of connected directors' political strength

\begin{tabular}{|c|c|c|c|c|c|c|c|c|c|c|}
\hline POLCON_RUL & \multirow[t]{2}{*}{$\begin{array}{c}0.026 * * * \\
(0.003)\end{array}$} & & $\begin{array}{c}0.049 * * * \\
(0.005)\end{array}$ & & \multirow[t]{2}{*}{$\begin{array}{c}0.063 * * \\
(0.020)\end{array}$} & & \multirow[t]{2}{*}{$\begin{array}{c}-0.007 * * * \\
(0.001)\end{array}$} & \multirow{2}{*}{\multicolumn{2}{|c|}{$\begin{array}{c}-0.027 * * \\
(0.009)\end{array}$}} & \multirow[b]{2}{*}{$\begin{array}{c}-0.042 * * \\
(0.013)\end{array}$} \\
\hline POLCON_RECENT & & $\begin{array}{c}0.040 * * * \\
(0.010)\end{array}$ & & $\begin{array}{c}0.057 * * \\
(0.018)\end{array}$ & & $\begin{array}{c}0.101 * * \\
(0.032)\end{array}$ & & & & \\
\hline Control Variables & Yes & Yes & Yes & Yes & Yes & Yes & Yes & Yes & Yes & Yes \\
\hline Firm fixed effects & Yes & Yes & Yes & Yes & Yes & Yes & Yes & Yes & Yes & Yes \\
\hline Industry $\times$ Time fixed effects & Yes & Yes & Yes & Yes & Yes & Yes & Yes & Yes & Yes & Yes \\
\hline Observations & 2401 & 2401 & 2401 & 2401 & 2401 & 2401 & 2401 & 2401 & 2401 & 2401 \\
\hline Number of firms & 343 & 343 & 343 & 343 & 343 & 343 & 343 & 343 & 343 & 343 \\
\hline \multirow[t]{5}{*}{ Adjusted $\mathrm{R}^{2}$} & 0.113 & 0.118 & 0.220 & 0.227 & 0.145 & 0.140 & 0.093 & 0.101 & 0.245 & 0.234 \\
\hline & \multicolumn{10}{|c|}{ Panel C: Impact of political connections across regulated and unregulated industries } \\
\hline & \multicolumn{4}{|c|}{ Firm performance } & \multicolumn{4}{|c|}{ Access to credit market } & \multicolumn{2}{|c|}{ Effective tax rate } \\
\hline & \multicolumn{2}{|c|}{ ROA } & \multicolumn{2}{|c|}{ Tobin's Q } & \multicolumn{2}{|c|}{ DEBT } & \multicolumn{2}{|c|}{ FINANCOST } & ETR & ETR \\
\hline & Regulated & Unregulated & Regulated & Unregulated & Regulated & Unregulated & Regulated & Unregulated & Regulated & Unregulated \\
\hline POLCON & $\begin{array}{c}0.025^{* * *} \\
(0.001)\end{array}$ & $\begin{array}{c}0.024 * * * \\
(0.004)\end{array}$ & $\begin{array}{c}0.043 * * \\
(0.011)\end{array}$ & $\begin{array}{c}0.045 * * \\
(0.014)\end{array}$ & $\begin{array}{c}0.073 * * \\
(0.021)\end{array}$ & $\begin{array}{c}0.069 * * * \\
(0.008)\end{array}$ & $\begin{array}{c}-0.010 * * \\
(0.003)\end{array}$ & $\begin{array}{c}-0.011 * * \\
(0.003)\end{array}$ & $\begin{array}{c}-0.019 * \\
(0.009)\end{array}$ & $\begin{array}{c}-0.022 * \\
(0.010)\end{array}$ \\
\hline Control Variables & Yes & Yes & Yes & Yes & Yes & Yes & Yes & Yes & Yes & Yes \\
\hline Firm fixed effects & Yes & Yes & Yes & Yes & Yes & Yes & Yes & Yes & Yes & Yes \\
\hline Industry $\times$ Time fixed effects & Yes & Yes & Yes & Yes & Yes & Yes & Yes & Yes & Yes & Yes \\
\hline Observations & 2401 & 2401 & 2401 & 2401 & 2401 & 2401 & 2401 & 2401 & 2401 & 2401 \\
\hline Number of firms & 343 & 343 & 343 & 343 & 343 & 343 & 343 & 343 & 343 & 343 \\
\hline Adjusted $\mathrm{R}^{2}$ & 0.240 & 0.219 & 0.343 & 0.320 & 0.400 & 0.419 & 0.176 & 0.181 & 0.226 & 0.234 \\
\hline
\end{tabular}




\section{TABLE 7: Robustness tests}

Panel A of this table presents the results without state-owned firms. Panel B presents the robustness test with industry adjusted variables. Panel $\mathrm{C}$ presents the robustness test with broader measure of political connection, which includes both the direct and indirect political connections. The variables used in the regressions are defined as follows. ROA is the ratio of firm's return (profit before taxes) over total assets. Tobin's Q is constructed as the market value of equity plus book value of total debts divided by the book value of total assets. DEBT is ratio of the book value of a firm's total debt (shortterm and long-term) to the total assets. FINANCOST is measured as interest expenses divided by total liabilities. ETR is the ratio of tax expenses minus deferred tax expenses divided by operating cash flow. In panel A\&B, POLCON is a dummy which takes one if there is a politician on board of directors, zero otherwise; whereas in panel C, it also include political ties through friends and families. Standard errors clustered at firm level are in parentheses beneath the coefficient estimates, where $* * * * *$ and $*$ denote statistical significance at the 1,5 and $10 \%$ levels, respectively.

\section{Panel A: Exclusion of state-owned firms}

\begin{tabular}{|c|c|c|c|c|c|}
\hline & \multicolumn{2}{|c|}{ Firm performance } & \multicolumn{2}{|c|}{ Access to credit market } & \multirow{2}{*}{$\begin{array}{c}\text { Effective tax rate } \\
\text { ETR } \\
(5)\end{array}$} \\
\hline & $\begin{array}{c}\text { ROA } \\
(1)\end{array}$ & $\begin{array}{c}\text { Tobin's Q } \\
\text { (2) }\end{array}$ & $\begin{array}{c}\text { DEBT } \\
\text { (3) }\end{array}$ & $\begin{array}{c}\text { FINANCOST } \\
\text { (4) }\end{array}$ & \\
\hline \multirow[t]{2}{*}{ POLCON } & $0.026 * * *$ & $0.042 * * *$ & $0.066^{* *}$ & $-0.009 * * *$ & $-0.020 * *$ \\
\hline & $(0.004)$ & $(0.010)$ & $(0.021)$ & $(0.000)$ & $(0.006)$ \\
\hline Control variables & Yes & Yes & Yes & Yes & Yes \\
\hline Firm fixed effects & Yes & Yes & Yes & Yes & Yes \\
\hline Industry $\times$ Time fixed effects & Yes & Yes & Yes & Yes & Yes \\
\hline Observations & 2401 & 2401 & 2401 & 2401 & 2401 \\
\hline Number of firms & 343 & 343 & 343 & 343 & 343 \\
\hline Adjusted $\mathrm{R}^{2}$ & 0.212 & 0.229 & 0.255 & 0.196 & 0.264 \\
\hline
\end{tabular}

Panel B: Industry adjusted variables

\begin{tabular}{lccccc}
\hline POLCON & $0.015^{* * *}$ & $0.032^{* *}$ & $0.062^{* *}$ & $-0.013^{* *}$ & $-0.027^{*}$ \\
& $(0.001)$ & $(0.010)$ & $(0.021)$ & $(0.005)$ & $(0.015)$ \\
Control variables & Yes & Yes & Yes & Yes & Yes \\
Firm fixed effects & Yes & Yes & Yes & Yes & Yes \\
Industry×Time fixed effects & Yes & Yes & Yes & Yes & Yes \\
Observations & 2401 & 2401 & 2401 & 2401 & 2401 \\
Number of firms & 343 & 343 & 343 & 343 & 343 \\
Adjusted R & 0.230 & 0.213 & 0.274 & 0.179 & 0.311 \\
\hline
\end{tabular}

Panel C: Alternative measure of political connections

\begin{tabular}{lccccc}
\hline POLCON & $0.023^{* * *}$ & $0.040^{* * *}$ & $0.072^{* * *}$ & $-0.020^{* * *}$ & $-0.033^{*}$ \\
& $(0.005)$ & $(0.007)$ & $(0.012)$ & $(0.000)$ & $(0.015)$ \\
Control variables & Yes & Yes & Yes & Yes & Yes \\
Firm fixed effects & Yes & Yes & Yes & Yes & Yes \\
Industry $\times$ Time fixed effects & Yes & Yes & Yes & Yes & Yes \\
Observations & 2401 & 2401 & 2401 & 2401 & 2401 \\
Number of firms & 343 & 343 & 343 & 343 & 343 \\
Adjusted $\mathrm{R}^{2}$ & 0.226 & 0.230 & 0.205 & 0.217 & 0.287 \\
\hline
\end{tabular}




\begin{tabular}{lccccc}
\hline \multicolumn{5}{c}{ Panel D: System GMM estimation technique } \\
\hline POLCON & $0.012^{* * *}$ & $0.024^{* * *}$ & $0.049^{* * *}$ & $-0.009^{* * *}$ & $-0.017^{* *}$ \\
& $(0.005)$ & $(0.007)$ & $(0.012)$ & $(0.000)$ & $(0.06)$ \\
Control variables & Yes & Yes & Yes & Yes & Yes \\
Year FE & Yes & Yes & Yes & Yes & Yes \\
Industry FE & Yes & Yes & Yes & Yes & Yes \\
Sargan test & 0.13 & 0.16 & 0.24 & 0.18 & 0.40 \\
AR-2 & 0.25 & 0.36 & 0.11 & 0.26 & 0.32 \\
Observations & 2401 & 2401 & 2401 & 2401 & 2401 \\
Number of firms & 343 & 343 & 343 & 343 & 343 \\
Adjusted R & 0.140 & 0.312 & 0.329 & 0.401 & 0.192 \\
\hline
\end{tabular}

